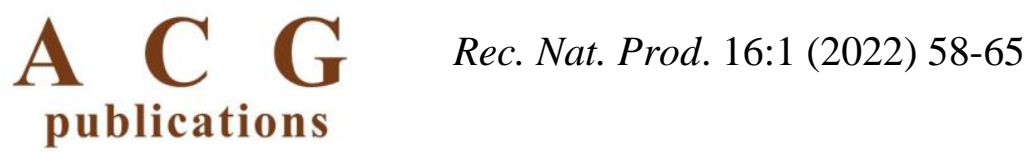

\title{
Chemical Constituents from the Roots of Calophyllum pisiferum Planch. \& Triana and Their Cytotoxic and Antioxidant Activities
}

\author{
Arnon Chukaew $\oplus^{1 *}$ and Prapaporn Chaniad $\oplus^{2}$ \\ ${ }^{I}$ Faculty of Science and Technology, Department of Chemistry, Suratthani Rajabhat University, \\ Suratthani 84100, Thailand \\ ${ }^{2}$ School of Medicine, Walailak University, Nakhon Si Tammarat 80160, Thailand
}

(Received April 20, 2021; Revised May 27, 2021; Accepted May 31, 2021)

\begin{abstract}
This is the first phytochemical investigation of the roots of Calophyllum pisiferum Planch. \& Triana. A new 4-phenyl coumarin, calopisifuran (1), and a new xanthone, 1-hydroxy-4,5-dimethoxyxanthone (2), were isolated and identified, together with 11 known compounds, including 4-phenyl coumarin (3-7) and xanthones (8-13). Their structures were elucidated by 1D- and 2D-NMR spectra and by HR-ESI-QTOF mass spectra and were compared with the literature data for known compounds. The isolated compounds exhibited significant cytotoxic activity in the MDA-MB-231, MCF-7 and A-549 cell lines, with $\mathrm{IC}_{50}$ values of 14.87, 23.56 and 43.34 $\mu \mathrm{g} / \mathrm{mL}$, respectively, for $\mathbf{1 0}$ and $\mathrm{IC}_{50}$ values of $17.15,45.76$ and $85.17 \mu \mathrm{g} / \mathrm{mL}$, respectively, for $\mathbf{1}$, while the DPPH assay revealed weak antioxidant activity.
\end{abstract}

Keywords: Clusiaceae; Calophyllum pisiferum; 4-phenyl coumarin; xanthone; cytotoxic. (C) 2021 ACG Publications. All rights reserved.

\section{Introduction}

Calophyllum is one of the largest genera of the Clusiaceae family. The members of this genus are widely distributed throughout Asia, and some species exist in Africa, the Americas, Australasia, and the Pacific Islands [1]. This genus includes approximately 187 species, of which 17 occur in Thailand [2]. Calophyllum is a rich source of secondary metabolites and has been reported to contain many bioactive compounds, such as coumarins, xanthones, flavonoids, triterpenes, benzofuran, acylphloroglucinol and chromanone; in particular, coumarins and xanthones [3] are found in almost all species and are well recognized as phytochemical markers for this genus. The biological activities of these types of compounds have been reported in some of the extracted pathways, and some of the isolated compounds have also shown good pharmaceutical activities, including cytotoxic activity [4], anti-HIV activity [5], antiviral activity, antitumor-promoting activity, antimalarial activity, antibacterial activity [3], anti-inflammatory activity [6] and central nervous system (CNS) activity [7]. Calophyllum pisiferum Planch. \& Triana, locally known as "Tung hon-bailek" in Thailand, is found only in lowland and swamp forests in southern Thailand [8], Cambodia, Indonesia, Malaysia, Myanmar and Vietnam. [9]. The wood of C. pisiferum has been used for the construction of dwellings, and there is no evidence for the utilization of this plant for folk medicine in Thailand.

\footnotetext{
*Corresponding author: E-Mail: arnoru_c@ hotmail.com; Phone: +66-87475-9856 Fax: +66-77-91-3348
} 
A literature survey showed that the chemical constituents and biological activities of this plant have not been reported. Therefore, we report herein the first isolation and structural elucidation of a new 4-phenyl coumarin compound (1) and a new xanthone (2) together with 11 known compounds (3-13) from the root of $C$. pisiferum (Figure 1). Some of the isolated compounds were tested for their cytotoxicity against the MCF-7, MDA-MB-231 and A-549 cell lines and for their antioxidant activities.

\section{Materials and Methods}

\subsection{General Experimental Procedures}

Melting points were determined by a Buchi melting point B-540 apparatus and were reported without correction. Optical rotations were measured on a JASCO P-1020 digital polarimeter. Ultraviolet spectra were measured in a methanol solution on a Biochrom Libra S50 UV/Vis spectrophotometer. IR spectra were measured for samples kept in the same holder with an IRTracer100 (Shimadzu) spectrophotometer. ${ }^{1} \mathrm{H}$ and ${ }^{13} \mathrm{C}$ NMR spectra were recorded on Bruker FTNMR Ultra Shield ${ }^{\mathrm{TM}} 300$ and $500 \mathrm{MHz}$ instruments $\left(300\right.$ and $500 \mathrm{MHz}$ for ${ }^{1} \mathrm{H}$ NMR and 125 and $75 \mathrm{MHz}$ for ${ }^{13} \mathrm{C}$ $\mathrm{NMR}) ; \mathrm{CDCl}_{3}$ and acetone- $d_{6}$ were used as solvents, and TMS was used as the internal standard. Chemical shifts were reported in $\delta$ [ppm], and the coupling constants $(J)$ were expressed in hertz. High-/low-resolution mass spectra were obtained by means of a mass spectrometer (Model: LCMS-ITTOF, Shimadzu). Quick column chromatography (QCC) and column chromatography (CC) were carried out on silica gel $60 \mathrm{GF}_{254}$ (Merck) and silica gel 100 (Merck), respectively. Preparative thinlayer chromatography (PTLC) was performed on precoated silica gel $60 \mathrm{GF}_{254}$ plates (Merck); spots were detected by UV and used for analysis. The solvents used for extraction and chromatography were distilled at their boiling points prior to use.

\subsection{Plant Material}

Roots of Calophyllum pisiferum Planch. \& Triana (Clusiaceae) was collected from Thung Khai, Yan Ta Khao District, Trang Province, Thailand, in December 2017. The plant was identified by Mr. Manop Poopath (Forestry Technical Officer), Forest Herbarium (BKF), and a voucher specimen (BKF No. 196969) was deposited at the Forest Herbarium (BKF), Department of National Parks, Wildlife and Plant Conservation, Chatuchak, Bangkok, Thailand.

\subsection{Extraction and Isolation}

The air-dried roots of $C$. pisiferum. $(5.2 \mathrm{~kg})$ were successively extracted with $\mathrm{CH}_{2} \mathrm{Cl}_{2}$ and acetone $\left(2 \times 20 \mathrm{~L}\right.$ for one week) at room temperature to furnish brownish viscous crude $\mathrm{CH}_{2} \mathrm{Cl}_{2}(43.6$ $\mathrm{g})$ and acetone $(10.1 \mathrm{~g})$ extracts. The crude $\mathrm{CH}_{2} \mathrm{Cl}_{2}$ extract was subjected to QCC over silica gel using hexane as the first eluent, and then the polarity was increased with $\mathrm{CH}_{2} \mathrm{Cl}_{2}$, EtOAc and acetone to give 10 fractions (F1-F10) based on TLC analysis. Fraction $3(3.26 \mathrm{~g})$ was purified by CC with 1:5 EtOAc/hexane to afford 6 subfractions $(3 \mathrm{~A}-3 \mathrm{~F})$. Subfraction 3C $(473.1 \mathrm{mg})$ was purified by CC with 1:4 EtOAc/hexane to give compounds $3(10.3 \mathrm{mg})$ and $\mathbf{6}(12.4 \mathrm{mg})$. Subfraction 3E (155.2 mg) was purified by CC (EtOAc/hexane, 1.5:3.5) to give $1(5.8 \mathrm{mg})$. Fraction $5(2.1 \mathrm{~g})$ was separated by CC (EtOAC/hexane, 1:5) to afford 5 subfractions (5A-5E). Subfraction 5C (154.6 mg) was further purified by CC (acetone/hexane, 2:5) to obtain $4(7.6 \mathrm{mg})$. Subfraction 5D (320.5 mg) was further purified by CC (EtOAC/hexane, 2.5:5) to yield $\mathbf{8}(27.6 \mathrm{mg})$. Fraction $6(6.2 \mathrm{~g})$ was separated by QCC over silica gel by elution with a solvent gradient from hexane to $\mathrm{CH}_{2} \mathrm{Cl}_{2}$ to $\mathrm{MeOH}$ to afford 6 subfractions (6A-6F). Subfraction 6B (187.2 $\mathrm{mg}$ ) was further purified by $\mathrm{CC}$ (EtOAC/hexane, 2.5:3.5) to give $10(12.1 \mathrm{mg})$ and $11(6.3 \mathrm{mg})$. Subfraction $6 \mathrm{D}(230.6 \mathrm{mg})$ was further purified by $\mathrm{CC}$ (acetone/hexane, 5:3.5) followed by PTLC (acetone/hexane, 2.5:4) to give $\mathbf{5}(1.2 \mathrm{mg}$ ) and 7 (3.8 $\mathrm{mg})$. 


\section{Chemical constituents from the roots of Calophyllum pisiferum}

Subfraction 8F (315.7 mg) was separated by CC (acetone/hexanes, 3:5) to afford $\mathbf{1 3}$ (12.4 mg), and subfraction $8 \mathrm{H}(96.4 \mathrm{mg})$ was purified by CC (EtOAc/hexanes, $1.5: 3.5)$ to afford $2(1.8 \mathrm{mg})$

The crude acetone extract was subjected to QCC and eluted with a gradient of hexane-acetone to afford 8 fractions (FA1-FA8). Fraction A4 (3.7 g) was isolated by CC (acetone/hexanes, 1:3.5) to afford 6 subfractions (A4A-A4F). Fraction A6 (2.3 g) was separated by CC (acetone/hexane, 2.5:3) to afford 5 subfractions (A6A-A6E). Subfraction A6C $(168.8 \mathrm{mg})$ was further purified by CC (acetone/hexane, 4:5) to yield $12(3.5 \mathrm{mg})$. Fraction A8 (1.3 g) was separated by CC (acetone/hexane, 3.5:4) to afford 4 subfractions (A8A-A8D). Subfraction A6C (107.6 mg) was further purified by CC (acetone/hexane, $4: 5)$ to give $\mathbf{9}(3.2 \mathrm{mg})$.

Calopisifuran (1): White solid; $[a]_{\mathrm{D}}{ }^{25}=+0.3(c 0.05, \mathrm{MeOH}) ; R_{f} 0.11$ (EtOAc/hexane, 1.5:3.5); UV $(\mathrm{MeOH}) \lambda_{\max }(\log \varepsilon) 235$ (3.32), 297 (4.06), 350 (3.24) and 370 (3.57) nm; IR (neat) $v_{\max }$ 3431, 1742, 1712 and $1597 \mathrm{~cm}^{-1} .{ }^{1} \mathrm{H}$ NMR $\left(\mathrm{CDCl}_{3}, 500 \mathrm{MHz}\right)$ and ${ }^{13} \mathrm{C} \mathrm{NMR}\left(\mathrm{CDCl}_{3}, 125 \mathrm{MHz}\right)$ spectroscopic data are provided in Table 1; HRESI-TOFMS: $\mathrm{m} / \mathrm{z} 361.0721[\mathrm{M}-\mathrm{H}]^{+}\left(\mathrm{Calcd}\right.$. for $\left[\mathrm{C}_{22} \mathrm{H}_{18} \mathrm{O}_{5}\right]^{-}$, 361.0726).

1-Hydroxy-4,5-dimethoxyxanthone (2):Yellow solid; $[a]_{\mathrm{D}}{ }^{25}=+0.7(c 0.05, \mathrm{MeOH}) ; R_{f} 0.10$ (EtOAc/hexanes, 1.5:3.5); UV (MeOH) $\lambda_{\max }(\log \varepsilon) 227$ (4.01), 255 (3.63), 317 (2.65) and 352 (3.86) $\mathrm{nm}$; IR (neat) $v_{\max } 3175,1655$ and $1589 \mathrm{~cm}^{-1} .{ }^{1} \mathrm{H} \mathrm{NMR}\left(\mathrm{CDCl}_{3}, 300 \mathrm{MHz}\right)$ and ${ }^{13} \mathrm{C} \mathrm{NMR}\left(\mathrm{CDCl}_{3}, 75\right.$ $\mathrm{MHz}$ ) spectroscopic data are provided in Table 1; HRESI-TOFMS: $m / z 273.0149[\mathrm{M}+\mathrm{H}]^{+}(\mathrm{Calcd}$. for $\left[\mathrm{C}_{15} \mathrm{H}_{12} \mathrm{O}_{5}\right]^{+}$, 273.0154).

\subsection{Bioassays}

\subsubsection{Cytotoxicity Assay}

The cytotoxicity was measured by a 3-(4,5-dimethylthiazol-2-yl)-2,5-diphenyltetrazolium bromide (MTT) assay [10]. The breast cancer cell line MCF-7, human breast adenocarcinoma cell line MDA-MB-231 and human lung carcinoma cell line A-549 were obtained from the American Type Culture Collection. Briefly, the cells were seeded at a density of $7 \times 10^{3}$ cells/well in 96 -well plates for $24 \mathrm{~h}$. The cells were then treated with various concentrations of the isolated compounds and incubated for $24 \mathrm{~h}$, and then the MTT formazan performance was measured at $570 \mathrm{~nm}$. Doxorubicin and ellipticine were used as standard drugs.

\subsubsection{Antioxidant Assay}

The antioxidant effect of the isolated compounds was determined using the 2,2'-diphenyl-1picrylhydrazyl (DPPH) free radical scavenging assay [11]. Trolox was used as a positive control. The scavenging activity was estimated based on the percentage of DPPH radicals scavenged by using the following equation:

$$
\text { Scavenging effect }(\%)=\frac{\text { control absorbance }- \text { sample absorbance }}{\text { control absorbance }} \times 100
$$

\section{Results and Discussion}

The $\mathrm{CH}_{2} \mathrm{Cl}_{2}$ and acetone extracts from the roots of $C$. pisiferum were subjected to repeated QCC over silica gel and PTLC to obtain a new 4-phenyl coumarin, namely, calopisifuran (1); a new xanthone, 1-hydroxy-4,5-dimethoxyxanthone (2); five known 4-phenyl coumarins, isomammeigin (3) [12], ponnalide (4) [13], 3,4-dihydro-5-hydroxy-2,2-dimethyl-6-(2-methylbutanoyl)-4-oxo-10-phenyl$2 H$-pyrano[2,3-f]chromen-8-one (5) [13], mammea A/AA deshydrocyclo F (6) [14], and 8,9-dihydro5-hydroxy-6-(2-methylbutanoyl)-4-phenyl-8-(prop-1-en-2-yl)furo[2,3-h]chromen-2-one (7) [13]; and six known xanthone compounds, mangostin (8) [15], macluraxanthone (9) [16], osajaxanthone (10) [17], tovophyllin A (11) [18], 1-hydroxy-3,7-dimethoxyxanthone (12) [19], and 1,3-dihydroxy-7- 
methoxyxanthone (13) [20]. The known compounds were identified by comparison with NMR data from the literature (Figure 1).<smiles>CC(C)CC(=O)c1c(O)c2c(-c3ccccc3)cc(=O)oc2c2ccoc12</smiles>

1<smiles>CCC(C)C(=O)c1c(O)c2c(c3c(-c4ccccc4)cc(=O)oc13)OC(C)(C)CC2=O</smiles><smiles>COc1cccc2c(=O)c3c(O)ccc(OC)c3oc12</smiles>

2<smiles>CC(C)CC(=O)c1c(O)c2c(c3c(-c4ccccc4)cc(=O)oc13)OC(C)(C)C=C2</smiles><smiles>CCC(C)C(=O)c1c(O)c2c(c3c(-c4ccccc4)cc(=O)oc13)OC(C)(C)C=C2</smiles><smiles>C=C(C)C1Cc2c(c(C(=O)CC(C)C)c(O)c3c(-c4ccccc4)cc(=O)oc23)O1</smiles><smiles>C=C(C)C1Cc2c(c(C(=O)C(C)CC)c(O)c3c(-c4ccccc4)cc(=O)oc23)O1</smiles><smiles>COc1c(O)cc2oc3cc(O)c(CC=C(C)C)c(O)c3c(=O)c2c1CC=C(C)C</smiles>

8<smiles>C=CC(C)(C)c1c2c(c(O)c3c(=O)c4ccc(O)c(O)c4oc13)C=CC(C)(C)O2</smiles>

9<smiles>CC1(C)C=Cc2c(cc3oc4ccc(O)cc4c(=O)c3c2O)O1</smiles>

10<smiles>CC(C)=CCc1c(O)cc2oc3c(CC=C(C)C)c(O)c4c(c3c(=O)c2c1O)C=CC(C)(C)O4</smiles><smiles>[R]c1cc(O)c2c(=O)c3cc(OC)ccc3oc2c1</smiles>

12: $\mathrm{R}^{1}=\mathrm{OMe}$

13: $\mathrm{R}^{1}=\mathrm{OH}$

Figure 1. Structures of compounds 1-13 from C. pisiferum.

\subsection{Structure Elucidation}

Compound (1) was isolated as a white solid, and the HRESI-TOFMS spectrum exhibited an $[\mathrm{M}-\mathrm{H}]^{+}$ion at $\mathrm{m} / z$ 361.0721, which corresponded to the molecular formula $\mathrm{C}_{22} \mathrm{H}_{18} \mathrm{O}_{5}$ and supported the identification as an unusual type of 4-phenylcoumarin chromophore [14]. The ${ }^{1} \mathrm{H}$ and ${ }^{13} \mathrm{C}$ NMR spectra of 1 (Table 1) displayed resonances of a chelated hydroxyl group at $\delta_{\mathrm{H}} 14.60,(\mathrm{~s}, 5-\mathrm{OH})$, revealing the presence three signals of five aromatic protons in the free phenyl group at $\delta_{\mathrm{H}} 7.44$, br d, $2 \mathrm{H}\left(\mathrm{H}-2^{\prime}\right.$ and $\left.\mathrm{H}-6^{\prime}, \delta_{\mathrm{C}} 127.7\right), 7.35, \mathrm{~m}, 2 \mathrm{H}\left(\mathrm{H}-3^{\prime}\right.$ and $\left.\mathrm{H}-5^{\prime}, \delta_{\mathrm{C}} 127.2\right)$ and $7.42, \mathrm{~m}, 1 \mathrm{H}\left(\mathrm{H}-4^{\prime} \delta_{\mathrm{C}} 128.4\right)$, and one singlet aromatic proton at $\delta_{\mathrm{H}} 6.16,(\mathrm{~s}, \mathrm{H}-3)$ was observed for the olefinic proton of a C-4substituted $\alpha$-pyrone ring system (4-phenyl coumarin core structure). The ${ }^{1} \mathrm{H}$ and ${ }^{13} \mathrm{C}$ NMR spectra (Table 1) also exhibited a methine proton at $\delta_{\mathrm{H}} 2.29\left(1 \mathrm{H}\right.$, sep, $\left.J=6.5, \mathrm{H}-3^{\prime \prime}, \delta_{\mathrm{C}} 25.0\right)$, a methylene proton at $\delta_{\mathrm{H}} 3.12,\left(2 \mathrm{H}, \mathrm{d}, J=6.5 \mathrm{~Hz}, \mathrm{H}_{2}-2^{\prime \prime}, \delta_{\mathrm{C}} 51.7\right)$, two methyl protons at $\delta_{\mathrm{H}} 1.02(6 \mathrm{H}, \mathrm{d}, J=6.5 \mathrm{~Hz}$, Me-4" and Me-5", $\left.\delta_{\mathrm{C}} 22.7\right)$ and a carbonyl carbon at $\delta_{\mathrm{C}} 204.3\left(\mathrm{C}-1^{\prime \prime}\right)$, and all these signals indicated the presence of a 3-methyl-1-oxobutyl group, confirming the side chain structure determined from COSY correlation data (Figure 2) and its location at C-6 determined from the HMBC (Figure 2) correlations of $\mathrm{H}_{2}-2^{\prime \prime}\left(\delta_{\mathrm{H}} 3.12\right)$ with C-6 ( $\left.\delta_{\mathrm{C}} 103.9\right)$. The spectra also showed doublet signals of two weakly coupled olefinic protons $\left[\delta_{\mathrm{H}} 7.66,1 \mathrm{H}, \mathrm{d}, J=2.0 \mathrm{~Hz}\left(\mathrm{H}-2^{\prime \prime \prime}\right)\right.$ and $7.15,1 \mathrm{H}, \mathrm{d}, J=2.0 \mathrm{~Hz}(\mathrm{H}-$ $\left.3^{\prime \prime \prime}\right)$ ], thus suggesting the presence of a furan moiety. The locations of furan ring associated with $\mathrm{C}-7$ and C-8 were determined by the HMBC correlations of H-2"' $\left(\delta_{\mathrm{H}} 7.66\right)$ with the carbons at C-7 $\left(\delta_{\mathrm{C}}\right.$ $156.1)$ and $\mathrm{C}-8\left(\delta_{\mathrm{C}} 109.8\right)$. Furthermore, the selected HMBC correlations of a chelated hydroxyl group at $\delta_{\mathrm{H}} 14.60(s, 5-\mathrm{OH})$ showed correlations to the carbons at C-4a $\left(\delta_{\mathrm{C}} 104.9\right), \mathrm{C}-5\left(\delta_{\mathrm{C}} 163.0\right)$ and C-6 $\left(\delta_{\mathrm{C}} 103.9\right)$, which, together with the NOESY correlation (Figure 2 ) between 5-OH and H-6', confirmed the position of a chelated hydroxyl group and a 3-methyl-1-oxobutyl group at C-5 and C-6, 


\section{Chemical constituents from the roots of Calophyllum pisiferum}

respectively. Additional evidence to support the isomer structure of $\mathbf{1}$ was obtained from the difference between their ${ }^{13} \mathrm{C}$ NMR data and those of isodisparfuran (Table S1, supplementary data) [14]. Therefore, compound $\mathbf{1}$ was named calopisifuran.

Compound (2) was obtained as a yellow solid with a molecular ion peak $[\mathrm{M}+\mathrm{H}]^{+}$at $\mathrm{m} / \mathrm{z}$ 273.0149 in the HRESI-TOFMS spectrum, which suggested a chemical formula of $\mathrm{C}_{15} \mathrm{H}_{12} \mathrm{O}_{5}$; in addition, the UV and IR spectra of this newly isolated compound had characteristic signals of a xanthone chromophore [21]. The ${ }^{1} \mathrm{H}$ NMR spectrum (Table 1) showed a chelated hydroxyl group at $\delta_{\mathrm{H}}$ $12.81(\mathrm{~s}, 1-\mathrm{OH})$, aided by the HMQC (Table 1) and COSY (Figure 2) spectra, which exhibited two ortho-doublet signals at $\delta_{\mathrm{H}} 7.06\left(\mathrm{~d}, J=9.0 \mathrm{~Hz}, \delta_{\mathrm{C}} 106.0\right)$ and $7.33\left(\mathrm{~d}, J=9.0 \mathrm{~Hz}, \delta_{\mathrm{C}} 120.9\right)$, and the positions of these ortho couples were placed at $\mathrm{H}-2$ and $\mathrm{H}-3$, respectively, due to the HMBC correlations (Figure 2$)$ of a chelated hydroxyl group (1-OH) with C-1 $\left(\delta_{\mathrm{C}} 150.7\right), \mathrm{C}-2\left(\delta_{\mathrm{C}} 106.0\right)$ and $\mathrm{C}-9 \mathrm{a}\left(\delta_{\mathrm{C}} 109.2\right)$ and NOESY correlations (Figure 2$)$ of a methoxy proton at $\delta_{\mathrm{H}} 3.96\left(\delta_{\mathrm{C}} 57.2\right)$ with an aromatic proton at $\delta_{\mathrm{H}} 7.33$ of $\mathrm{H}-3(4-\mathrm{OMe} \leftrightarrow \mathrm{H}-3)$. The remaining peaks indicated three adjacent aromatic protons in the ABM pattern at $\delta_{\mathrm{H}} 7.25\left(\mathrm{dd}, J=8.5,2.0 \mathrm{~Hz}, \mathrm{H}-6, \delta_{\mathrm{C}} 116.1\right), 7.32(\mathrm{t}, J=8.5$ $\left.\mathrm{Hz}, \mathrm{H}-7, \delta_{\mathrm{C}} 123.4\right)$ and $7.85\left(\mathrm{dd}, J=8.5,2.0 \mathrm{~Hz}, \mathrm{H}-8, \delta_{\mathrm{C}} 116.9\right)$ and methoxy groups at $\delta_{\mathrm{H}} 4.04\left(\delta_{\mathrm{C}}\right.$ 56.5). This methoxy group was located at C-5, as determined from the HMBC correlation (Figure 2) with $\mathrm{C}-5\left(\delta_{\mathrm{C}} 148.5\right)$ and confirmed by the positions in the ABM aromatic proton system of H-6 at $\delta_{\mathrm{H}}$ 7.25 correlated with C-5 $\left(\delta_{\mathrm{C}} 148.5\right), \mathrm{H}-7$ at $\delta_{\mathrm{H}} 7.32$ correlated with C-5 $\left(\delta_{\mathrm{C}} 148.5\right)$ and C-8a $\left(\delta_{\mathrm{C}} 118.5\right)$ and $\mathrm{H}-8$ at $\delta_{\mathrm{H}} 7.85$ correlated with C-6 $\left(\delta_{\mathrm{C}} 116.1\right)$ and C-9 $\left(\delta_{\mathrm{C}} 183.0\right)$ and the NOESY correlations between 5-OMe and H-6, as shown in Figure 2. Furthermore, a comparison of the carbon chemical shift of 1-hydroxy-4,5-dimethxoyxanthone in compound 2 was different from that of 1,8-dihydroxy-2methoxyxanthone (Table S2, supplementary data) [22]. Thus, from the above data, the structure of compound 2 was elucidated as 1-hydroxy-4,5-dimethoxyxanthone.

Table 1. ${ }^{1} \mathrm{H}$ and ${ }^{13} \mathrm{C}$ NMR spectral data for compounds $\mathbf{1}$ and $\mathbf{2}$

\begin{tabular}{|c|c|c|c|c|}
\hline \multirow[t]{2}{*}{ Position } & \multicolumn{2}{|c|}{$1^{\mathrm{a}}$} & \multicolumn{2}{|c|}{$2^{b}$} \\
\hline & $\delta_{\mathrm{H}}(J$ in Hz $)$ & $\delta_{\mathrm{C}}($ type $)$ & $\delta_{\mathrm{H}}(J$ in $\mathrm{Hz})$ & $\delta_{\mathrm{C}}($ type $)$ \\
\hline 1 & & & & $150.7(\mathrm{C})$ \\
\hline 2 & & $159.3(\mathrm{C})$ & 7.06, d (9.0) & $106.0(\mathrm{CH})$ \\
\hline 3 & $6.16, \mathrm{~s}$ & $114.4(\mathrm{CH})$ & $7.33, \mathrm{~d}(9.0)$ & $120.9(\mathrm{CH})$ \\
\hline 4 & & $156.8(\mathrm{C})$ & & 142.8 (C) \\
\hline $4 a$ & & 104.9 (C) & & 149.8 (C) \\
\hline 5 & & $163.0(\mathrm{C})$ & & 148.5 (C) \\
\hline 6 & & 103.9 (C) & $7.25, \mathrm{dd}(8.5,2.0)$ & $116.1(\mathrm{CH})$ \\
\hline 7 & & $156.1(\mathrm{C})$ & $7.32, \mathrm{t}(8.5)$ & $123.4(\mathrm{CH})$ \\
\hline 8 & & $109.8(\mathrm{C})$ & $7.85, \mathrm{dd}(8.5,2.0)$ & $116.9(\mathrm{CH})$ \\
\hline $8 \mathrm{a}$ & & $153.5(\mathrm{C})$ & & $118.5(\mathrm{C})$ \\
\hline 9 & & & & $183.0(\mathrm{C})$ \\
\hline $9 \mathrm{a}$ & & & & $109.2(\mathrm{C})$ \\
\hline 10a & & & & $147.0(\mathrm{C})$ \\
\hline $1^{\prime}$ & & $139.0(\mathrm{C})$ & & \\
\hline $2^{\prime}, 6^{\prime}$ & 7.44, br d & $127.7(\mathrm{CH})$ & & \\
\hline $3^{\prime}, 5^{\prime}$ & $7.35, \mathrm{~m}$ & $127.2(\mathrm{CH})$ & & \\
\hline $4^{\prime}$ & $7.42, \mathrm{~m}$ & $128.4(\mathrm{CH})$ & & \\
\hline $1^{\prime \prime}$ & & 204.3 (C) & & \\
\hline $2^{\prime \prime}$ & $3.12, \mathrm{~d}(6.5)$ & $51.7\left(\mathrm{CH}_{2}\right)$ & & \\
\hline $3^{\prime \prime}$ & $2.29, \operatorname{sep}(6.5)$ & $25.0(\mathrm{CH})$ & & \\
\hline $4^{\prime \prime}, 5^{\prime \prime}$ & $1.02, \mathrm{~d}(6.5)$ & $22.7\left(\mathrm{CH}_{3}\right)$ & & \\
\hline $2^{\prime \prime \prime}$ & $7.66, \mathrm{~d}(2.0)$ & $143.9(\mathrm{CH})$ & & \\
\hline 3"' & $7.15, \mathrm{~d}(2.0)$ & $104.7(\mathrm{CH})$ & & \\
\hline $1-\mathrm{OH}$ & & & $12.81, \mathrm{~s}$ & \\
\hline $5-\mathrm{OH}$ & $14.60, \mathrm{~s}$ & & & \\
\hline 4-OMe & & & $3.96, \mathrm{~s}$ & $57.2\left(\mathrm{CH}_{3}\right)$ \\
\hline $5-\mathrm{OMe}$ & & & $4.04, \mathrm{~s}$ & $56.5\left(\mathrm{CH}_{3}\right)$ \\
\hline
\end{tabular}

${ }^{\mathrm{a}}$ Recorded at $500 \mathrm{MHz}$ in $\mathrm{CDCl}_{3}$.

${ }^{\mathrm{b}}$ Recorded at $300 \mathrm{MHz}$ in $\mathrm{CDCl}_{3}$. 

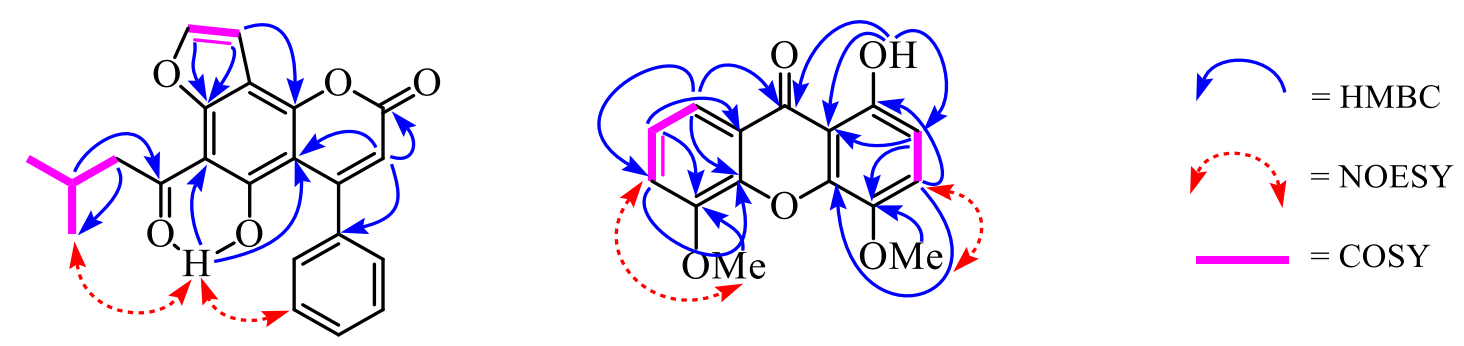

Figure 2. The key COSY, NOESY and HMBC correlations for calopisifuran (1) and 1-hydroxy-4,5-dimethoxyxanthone (2)

\subsection{Cytotoxicity and Antioxidant Activity}

Evaluations of the cytotoxic effects of compounds $1,3, \mathbf{6}, \mathbf{8}, \mathbf{1 0}$ and 13 (Table 2) against the breast cancer cell line MCF-7, the human breast adenocarcinoma cell line MDA-MB-231 and the human lung carcinoma cell line A-549 were performed by MTT assay, with doxorubicin and ellipticine as the positive controls. Compound $\mathbf{1 0}$ was found to possess the highest potency, showing moderate cytotoxicity against the MDA-MB-231, MCF-7 and A-549 cell lines, with $\mathrm{IC}_{50}$ values of 14.87, 23.56 and $43.34 \mu \mathrm{g} / \mathrm{mL}$, respectively. New compound 1 exhibited cytotoxicity against the MDA-MB-231, MCF-7 and A-549 cell lines with $\mathrm{IC}_{50}$ values of $17.15,45.76$ and $85.17 \mu \mathrm{g} / \mathrm{mL}$, respectively. Compound 6 exhibited cytotoxicity against the MDA-MB-231, MCF-7 and A-549 cell lines with $\mathrm{IC}_{50}$ values of $23.14,40.23$ and $65.77 \mu \mathrm{g} / \mathrm{mL}$, respectively. In addition, compounds $\mathbf{3}, \mathbf{8}$ and 13 exhibited weak to no cytotoxicity. In addition, compounds $3,4,6,8,10,11$ and 13 were evaluated for their antioxidant properties and the ability to scavenge a stable DPPH free radical. The results revealed that all of the tested compounds, exhibited weak antioxidant activity, with DPPH radical scavenging percentages of $34.56,46.23,45.78,11.23,8.65,0.84$ and $49.54 \%$, respectively.

Table 2. Cytotoxic activities of some isolated compounds from C. pisiferum

\begin{tabular}{cccc|c}
\hline \multirow{2}{*}{ Compounds } & \multicolumn{3}{c|}{ Cytotoxic activity $\left(\mathbf{I C}_{\mathbf{5 0}}, \boldsymbol{\mu g} / \mathbf{m L}\right)$} & $\begin{array}{c}\text { \% Radical } \\
\text { scanging ability }\end{array}$ \\
\cline { 2 - 5 } & MCF-7 & MDA-MB-231 & $\mathbf{A - 5 4 9}$ & DPPH \\
\hline $\mathbf{1}$ & $45.76 \pm 1.49^{*}$ & $17.15 \pm 0.94^{*}$ & $85.17 \pm 1.02^{*}$ & $\mathrm{ND}$ \\
$\mathbf{3}$ & $>100$ & $>100$ & $>100$ & $11.23 \pm 1.01^{*}$ \\
$\mathbf{4}$ & $\mathrm{ND}$ & $\mathrm{ND}$ & $\mathrm{ND}$ & $8.65 \pm 0.47^{*}$ \\
$\mathbf{6}$ & $40.23 \pm 1.01^{*}$ & $23.14 \pm 0.41^{*}$ & $65.77 \pm 1.43^{*}$ & $0.84 \pm 0.03^{*}$ \\
$\mathbf{8}$ & $85.33 \pm 0.99^{*}$ & $76.17 \pm 0.52^{*}$ & $94.65 \pm 0.44^{*}$ & $34.56 \pm 1.16^{*}$ \\
$\mathbf{1 0}$ & $23.56 \pm 0.61^{*}$ & $14.87 \pm 0.79^{*}$ & $43.34 \pm 0.59^{*}$ & $46.23 \pm 0.68^{*}$ \\
$\mathbf{1 1}$ & $\mathrm{ND}$ & $\mathrm{ND}$ & $\mathrm{ND}$ & $49.54 \pm 0.91^{*}$ \\
$\mathbf{1}$ & $>100$ & $89.32 \pm 0.48^{*}$ & $>100$ & $45.78 \pm 0.58^{*}$ \\
Doxorubicin & $2.30 \pm 0.12$ & $\mathrm{ND}$ & $2.50 \pm 0.18$ & $\mathrm{ND}$ \\
Ellipticine & $\mathrm{ND}$ & $1.70 \pm 0.17$ & $\mathrm{ND}$ & $\mathrm{ND}$ \\
Trolox $\left(\mathrm{IC} \mathrm{I}_{50} ; \mathrm{mg} / \mathrm{L}\right)$ & $\mathrm{ND}$ & $\mathrm{ND}$ & $\mathrm{ND}$ & $77.70 \pm 1.00$ \\
\hline
\end{tabular}

*Statistically significant difference between the positive control and sample, $p<0.05$ (mean \pm SD of three determinations); ND = not determined

\section{Conclusion}

In this study, a new 4-phenyl coumarin (1) and a new xanthone (2), along with eleven known compounds (3-13), were isolated from the roots of $C$. pisiferum for the first time, and all the compounds were characterized by means of on spectroscopic methods and by comparison with previously reported data. New compound $\mathbf{1}$ and compound $\mathbf{1 0}$ showed significant cytotoxicity against the MDA-MB-231 cell line, whereas the remaining compounds showed weak antioxidant activity. 


\section{Acknowledgments}

Suratthani Rajabhat University (SRU) is acknowledged for providing laboratory facilities. We are grateful to the Laboratory of Natural Products Chemistry, Faculty of Science and Technology, Phuket Rajabhat University, for providing instruments. The Department of Chemistry, Prince of Songkla University, provided the facilities used in this research. We acknowledge Assoc. Prof. Chanita Ponglimanont for helpful suggestions and Dr. Abdul-Wahab Salae for recording the NMR spectra.

\section{Supporting Information}

Supporting information accompanies this paper at http://www.acgpubs.org/journal/records-ofnatural-products

\section{Disclosure Statement}

The authors declare that we have no conflicts of interest in this paper.

\section{ORCID}

Arnon Chukaew: 0000-0002-9411-4740

Prapaporn Chaniad: 0000-0002-3624-458X

\section{References}

[1] X. W. Li, J. Li and P. Stevens (2007). Calophyllum Linnaeus, Sp. Pl. 1: 513. 1753, Flora of China 13, 38

[2] S. Sungkaew, S. Pongumpai, D. Sookchaloen and T. Santisuk (2009). The Genus Calophyllum (Guttiferae) in Thailand, J. Forest Manage. 3, 2552-2575.

[3] X. H. Su, M. L. Zhang, L. G. Li, C. H. Huo, Y. C. Gu and Q. W. Shi (2008). Chemical constituents of the plants of the genus Calophyllum, Chem Biodivers. 5, 2579-2608.

[4] N. H. Zamakshshari, G. C. L. Ee, I. S. Ismail, Z. Ibrahim and S. H. Mah (2019). Cytotoxic xanthones isolated from Calophyllum depressinervosum and Calophyllum buxifolium with antioxidant and cytotoxic activities, Food Chem. Toxicol. 133, 110800.

[5] C. Spino, M. Dodier and S. Sotheeswaran (1998). Anti-HIV coumarins from Calophyllum seed oil, Bioorg. Med. Chem. Lett. 8, 3475-3478.

[6] S. H. Mah, S. S. Teh and G. C. L. Ee (2019). Comparative studies of selected Calophyllum plants for their anti-inflammatory properties, Pharmacogn. Mag. 15, 135.

[7] A. J. Alonso-Castro, S. L. Guzmán-Gutiérrez, C. A. Betancourt, D. Gasca-Martínez, K. L. AlvarezMartínez, M. Pérez-Nicolás, C. I. Espitia-Pinzón and R. Reyes-Chilpa (2018). Antinociceptive, anti-inflammatory, and central nervous system (CNS) effects of the natural coumarin soulattrolide, Drug Dev. Res. 79, 332-338.

[8] T. Smitinand (2014). Thai Plants Names. Forest Herbarium, Royal Forest Department, Bangkok.

[9] World Conservation Monitoring Centre (1998). Calophyllum pisiferum, The IUCN Red List of Threatened Species 1998: e.T37667A10069821. Retrieved 20 December 2019. https://dx.doi.org/10.2305/IUCN.UK.1998.RLTS.T37667A10069821.en.

[10] S. Rattanaburi, M. Daus, R. Watanapokasin and W. Mahabusarakam (2014). A new bisanthraquinone and cytotoxic xanthones from Cratoxylum cochinchinense, Nat. Prod. Res. 28, 606-610.

[11] B. Hazra, S. Biswas and N. Mandal (2008). Antioxidant and free radical scavenging activity of Spondias pinnata, BMC Complement. Altern. Med. 8, 1-10. 
[12] R. Reyes-Chilpa, E. Estrada-Muñiz, T. R. Apan, B. Amekraz, A. Aumelas, C. K. Jankowski and M. Vázquez-Torres (2004). Cytotoxic effects of mammea type coumarins from Calophyllum brasiliense, Life Sci. 75, 1635-1647.

[13] L. Verotta, E. Lovaglio, G. Vidari, P. V. Finzi, M. G. Neri, A. Raimondi and E. Bombardelli (2004). 4Alkyl-and 4-phenylcoumarins from Mesua ferrea as promising multidrug resistant antibacterials, Phytochemistry 65, 2867-2879.

[14] D. Guilet, J. J. Hélesbeux, D. Séraphin, T. Sévenet, P. Richomme and J. Bruneton (2001). Novel Cytotoxic 4-Phenylfuranocoumarins from Calophyllum dispar, J. Nat. Prod. 64, 563-568.

[15] S. B. Daud, G. C. L Ee, E. A. Malek, S. S. Teh and I. See (2014). A new coumarin from Calophyllum hosei, Nat. Prod. Res. 28, 1534-1538.

[16] M. Iinuma, H. Tosa, T. Tanaka and S. Yonemori (1994). Two new xanthones in the underground part of Calophyllum inophyllum, Heterocycles 37, 833-838.

[17] Z. Huang, R. Yang, Z. Guo, Z. She and Y. Lin (2010). A new xanthone derivative from mangrove endophytic fungus No. ZSU-H16, Chem. Nat. Compd. 46, 348-351.

[18] W. G. De Oliveira, O. R. Gottlieb and A. L. Mesquita (1972). Xanthones from Tovomita macrophylla, Phytochemistry 11, 3323-3325.

[19] F. J. Q. Monte, F. P. Soares and R.Braz-Filho (2001). A xanthone from Shultesia guianensis, Fitoterapia 72, 715-716.

[20] T. R. Pinheiro, V. Cechinel Filho, A. R. Santos, J. B. Calixto, F. Delle Monache, M. G. Pizzolatti and R. A Yunes (1998). Three xanthones from Polygala cyparissias, Phytochemistry 48, 725-728.

[21] N, Boonnak, C. Karalai, S. Chantrapromma, C. Ponglimanont, H. K. Fun, A. Kanjana-Opas and S. Laphookhieo (2006). Bioactive prenylated xanthones and anthraquinones from Cratoxylum formosum ssp. pruniflorum, Tetrahedron 62, 8850-8859.

[22] E. K. Wijeratne, T. J. Turbyville, A. Fritz, L. Whitesell and A. L. Gunatilaka (2006). A new dihydroxanthenone from a plant-associated strain of the fungus Chaetomium globosum demonstrates anticancer activity, Bioorg Med Chem. 14, 7917-7923.

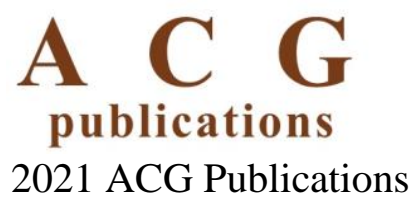

